the enterprise may be obtained. The whole was a triumph of self-registration devices. Contributions of instruments were made by educational and other institutions in many parts of the United States. There were tubes of spore cultures, three spectrographs, one for ozone, one for sky and one for horizon ; three electroscopes for cosmic ray ionisation, one exposed, one inside 4 in. of lead shielding and another weighing $600 \mathrm{lb}$. with a 6 in. covering of lead. These were contributed by Millikan and Neher. A contribution by Swann and Locher was a counter apparatus arranged for recording cosmic ray intensity from four different directions from the vertical to the horizontal. There were coarse and inter-range barometers for recording pressure variations automatically at high altitudes, and a dozen or more parachutes for men, heavy instruments and gondola.

Besides a perfect barograph record of the event which shows that a minimum pressure of $60 \mathrm{~mm}$. was reached, electroscope records of cosmic ray ionisation from ground-level to $60,000 \mathrm{ft}$. were obtained. These have led Millikan to the conclusion that the only source of the observed cosmic ray energies now in sight is matter annihilation : most of the ionisation observed at sea-level is due to incoming photons produced during the destruction of matter in higher altitudes. Records of sun and sky brightness, internal and external temperature, the altitude of the inversion of the temperature gradient between $20,000 \mathrm{ft}$. and $38,000 \mathrm{ft}$., were also obtained. Capt. Stevens concludes by saying, "our most eheering thought of the recent ascent is that we feel we have successfully solved the problems of living and working efficiently in the stratosphere . . . not a single piece of scientific equipment attached to the gondola failed us during the flight ; every instrument worked exactly as planned".

The mishap was due to a rip in the lower part of the balloon which was first noticed at the highest altitude. The men owe their lives to the perfection of the carefully designed scalloped band attached to the balloon fabric to which the gondola was roped. This band held the balloon steady in a drop of about $55,000 \mathrm{ft}$. in about $1 \frac{1}{2}$ hours and kept the rips from extending.

\section{Inheritance of Anatomical Structure in Plants}

$\mathrm{T}$ HERE have been very few investigations of the inheritance of anatomical structure in plants. A recently issued work by $\mathrm{E}$. W. Sinnott, Helen Houghtaling and A. F. Blakeslee* is a contribution to this subject, based on a comparison of the vascular anatomy in, $(a)$ the polyploid forms of Datura $(n, 2 n$, $3 n, 4 n)$, and $(b)$ the 12 trisomic $(2 n+1)$ mutants and such of their secondaries as were available. Among the few earlier studies, the authors have overlooked the work of Penhallow on the anatomy of a hybrid Catalpa, and the papers of Gates and Bartlett on cell measurements in tetraploid Enothera.

The flower pedicel was chosen for anatomical study, as comparable material could most easily be obtained from this region. Seventeen anatomical traits of this structure were quantitatively studied. In the polyploid series, as in previous results, there was progressive increase in size of the structure and its constituent cells, but not always in the proportion

* The Comparative Anatomy of Extra-Chromosomal Types in Datura stramonium. By Edmund W. Sinnott, Helen Houghtaling plates. (Washington, D.C.: Carnegie Institution, 1934.) expected. The cortex was relatively large in the haploid, and relatively small in the $3 n$ and $4 n$ mutants, the smaller cortex being due to fewer cells. These facts, and others from the heteroploid series, lead to the conclusion that cell size and cell number are independently controlled.

There were certain exceptions to the increasing cell size in the polyploid series. The pericycle fibres remain of the same size, perhaps because they are frequently found to be multinucleate. The leaves increase in thickness, due to increase in cell size and elongation of the palisade cells, those of the tetraploid having at least twelve times the volume of those in the haploid. Similarly the petiole in cross-section is about sixteen times as large in the tetraploid as in the haploid, the same applying generally to the cells, which therefore show a geometric rather than an arithmetic ratio of increase.

In the heteroploid series, all having 25 chromosomes, the anatomical differences were equally marked and were due to the genic constitution of the extra chromosome. Certain of the primaries, such as 'spinach', were even larger than the tetraploid, this being due almost entirely to larger cell size. Different elements of the anatomy show considerable independence in their response to the presence of specific chromosomes. The conception of genic balance applies very well to some of the secondaries in comparison with their primaries, but this is by no means always the case, and various attempts are made to explain aberrant results. Curious facts which emerge are that the starch grains, especially in the secondaries, may have a very large or very small mean size, and that while the style of the flower has two vascular bundles in the $2 n, 3 n$ and $4 n$ forms, in the haploid it always has five or six.

\section{University and Educational Intelligence}

Cambridge.-Prof. R. H. Tawney, of the University of London, has been appointed Alfred Marshall lecturer for 1934-35.

Dr. T. S. Hele has been appointed assessor to the Regius professor of physic.

Trinity College announces the offer of a research studentship open to graduates of other universities who propose to go to Cambridge in October next as candidates for the degree of Ph.D. Dominion and Colonial exhibitions are also offered to students of Dominion and Colonial universities who wish to go to Cambridge next October as candidates for the degree of B.A., M.Litt., M.Sc., or Ph.D. Further information can be obtained from the Senior Tutor, and applications should reach him by July 1, 1935.

MANCHESTER.-In connexion with the meeting of the Chemical Society to be held in the University on November 9 and 10, a reunion dinner of past and present members of the Department of Chemistry has been arranged; arrangements are in the hands of Drs. G. N. Burkhardt and C. E. H. Bawn of the Chemistry Department. A party of a hundred fellows of the Chemical Society will visit the Shirley Institute of the British Cotton Industry Research Association on November 9.

The following resignations and appointments have been announced this session :-Mr. F. W. Priestley has been appointed lecturer in veterinary bacteriology in succession to Mr. C. A. MeGaughey, resigned. Dr. 
R. W. Fairbrother has been appointed lecturer in bacteriology, and has vacated the assistant directorship of the Routine Section of the Department of Bacteriology and Preventive Medicine, to which Dr. J. C. Kerrin has been appointed. Mr. D. T. Robinson has been appointed assistant lecturer in bacteriology, and Messrs. I. A. Cathie and James Dawson demonstrators in pathology.

OXFord.-The preamble of a statute designed to promote the more effective co-operation between Council and Congregation has passed the latter body without opposition.

Congregation has empowered the professor of zoology and comparative anatomy to continue, under the title of "Bureau of Animal Population", the provision made in his department for research into the ecology of wild mammals and for the coordination of data obtained from published sources and from field observers.

Dr. R. T. Gunther, the newly appointed reader in the history of science, delivered his inaugural lecture on October 25. He lamented the disappearance of many of the original instruments used by the pioneers of scientific research, as, for example, the air-pump of Boyle and Hooke; in many cases the actual instruments were more needed than even the records. In paying a tribute to the memory of Daubeny, he mentioned that among those who attended Daubeny's lectures were Sir John Bennet Lawes, Pusey, Mark Pattison, Ruskin and Acland.

American education is about to receive a powerful impulse towards co-operative unification through the agency of the American Council on Education. This body, founded in 1918 with the object of organising co-operative effort in relation to problems of higher education, is now extending its activities to include the entire educational field. This development was announced at the Council's annual meeting at Washington on May 18, a summary account of which was published in School and Society of May 26. It was made possible by grants from a number of educational foundations: the General Education (Rockefeller) Board, 300,000 dollars; Julius Rosenwald Fund, 20,000 dolląrs ; Carnegie Corporation, 20,000 dollars ; Josiah Macy Junior Foundation, 12,000 dollars. In a report entitled "Integration", the Council's director, Dr. C. R. Mann, traces the steps by which it was arrived at. In a significant passage, the report declares : "We in America have kept the development and control of schools independent of political government . . agencies created by the people to help them achieve their aspirations. In other countries schools are agencies created by government for such uses as government may choose to make of them". It is to provide the leadership needed for the perpetuation of this American system in the face of the manifold pressures of the rapidly changing social economy of to-day that the Council is undertaking such a radical enlargement of the scope of its work, and it is significant that the Council has elected as its new director, in succession to Dr. Mann, Dr. George F. Zook, who has resigned his post as United States Commissioner of Education. Dr. Zook has declared that the influence which led him to resign was the conviction that the Council, on its new basis of activity, seemed to present "a wonderful opportunity for service in formulating fundamental policies in education now so needed".

\section{Science News a Century Ago}

\section{Gas Lighting at the Royal Institution}

In 1834 the lecture room and adjacent parts of the Royal Institution were lighted by oil gas supplied by the Portable Gas Company. The compressed gas was delivered regularly to the Institution in metal containers, which were connected up to the pipe system. It will be remembered that in 1825 Faraday had separated the new compound bicarburet of hydrogen (benzene) by distillation of the condensed oil gas liquor which collected in the vessels used by the Company.

On November 3, 1834, Prof. Faraday reported to the Managers that, owing to the dissolution of the Portable Gas Company, new arrangements must be made for the lighting of the Institution. It was resolved to use coal gas. A few weeks later the Managers were informed that the new supply had been laid on to the building, the pipes and fittings used for oil gas had been adapted for the coal gas, and the system found to give a satisfactory and sufficient light without further change.

\section{Aurora Borealis of November 3, 1834}

In the Memoirs of the Literary and Philosophical Society of Manchester (6, Ser. 2, 1842) a paper, originally communicated by John Dalton, is printed (though long delayed in issue), referring to an aurora borealis of date November 3, 1834. Dalton reports that "in the evening I. observed a horizontal light very conspicuous in the magnetic north; it continued without much change for two or three hours. A little before eight o'clock (true mean time), I was informed by two of my pupils that a fine arch to the south was observable; on looking I beheld a beautiful and brilliant arch crossing the magnetic meridian at right angles; its summit was $10^{\circ}+$ to the south of the zenith, about 4 to 5 degrees broad, and extending from about 20 degrees altitude east to 20 degrees west. The appearance of an auroral arch such as was presented . .. is a rare phenomenon. I do not remember to have seen more than one before, and that was nearly forty-two years since. I believe no modern meteorologist has expressed a doubt that this arch-like appearance in the sky is only a modification of the more common appearance of the Aurora Borealis. I have for the last forty years considered both arches and beams to be constituted of magnetic matter, and in ordinary circumstances invisible; but when a disturbance of the electric fluid takes place in the upper regions these beams, etc., serve to convey the electric fluid from one place to another to restore the equilibrium, which occasions the luminous appearances."

\section{Celestial Phenomenon seen at Liverpool}

On November 7, the Times published a letter from a correspondent, "J. B.", and also an extract from the Liverpool Courier, relating to an interesting spectacle seen at Liverpool on November 3 . The account in the paper said that "on Monday evening, about 8 o'clock, a singular luminous appearance was seen in the heavens commencing near the western horizon and after extending through the meridian of the heavens, finally losing itself near the brilliant planet Jupiter ... It presented the aspect of a beauteous transparent zone of light, of near equal width, from six to seven degrees. .. The stars 